\title{
Niche indications could drive higher valuations
}

Foster City, California-based Gilead surprised Wall Street with a proposal to purchase Westminster, Colorado-based Myogen on October 2, 2006 in a tender offer of \$2.5 billion in cash. The acquisition could demonstrate that companies with niche applications are becoming more attractive to betterestablished biopharmaceutical companies. As a result, increased valuation for those niche biotech companies could follow.

Some shareholders complained that Gilead paid too steep a price for Myogen. Lost amidst the shareholder's grumbles were the instructive footnotes by analysts recognizing the strategic importance of the acquisition. Rodman \& Renshaw analyst Michael G. King of New York called the move "strategically bold" and said that Myogen's agents had "blockbuster potential." The company's two lead products, ambrisentan and darusentan-respectively in phase 3 and 2 trials-are endothelin receptor antagonists developed to treat pulmonary arterial hypertension.

Karen Andersen, Chicago-based biotech analyst for Morningstar, the independent stock market research house, thinks that the acquisition is as much about managing earnings in the future as it is about strategic positioning. The Myogen acquisition helps cover a pipeline gap that Gilead faces that could impact earnings. Going from a hand-to-mouth research existence to planning for future earnings and growth is a significant milestone for a biotech company in an industry which has often seen companies rely only on one or two compounds to stay in business.

There has been a growing realization inside the industry that there is money to be made in smaller indications. "A lot of the companies that I am focusing on seem to be getting more involved in niche [indication] areas," says Andersen. "Even cancer indications are getting more focused." As disease mechanisms are better understood to be a combination of heredity and environment, more indications are highly targeted at specific populations. Genzyme of Cambridge, Massachusetts was among the first companies to demonstrate that it was possible to generate big sales figures for niche products with its enzyme replacement treatment for type 1 Gaucher disease and Fabry disease.

The result could be increased valuations for niche indications. But while Doug

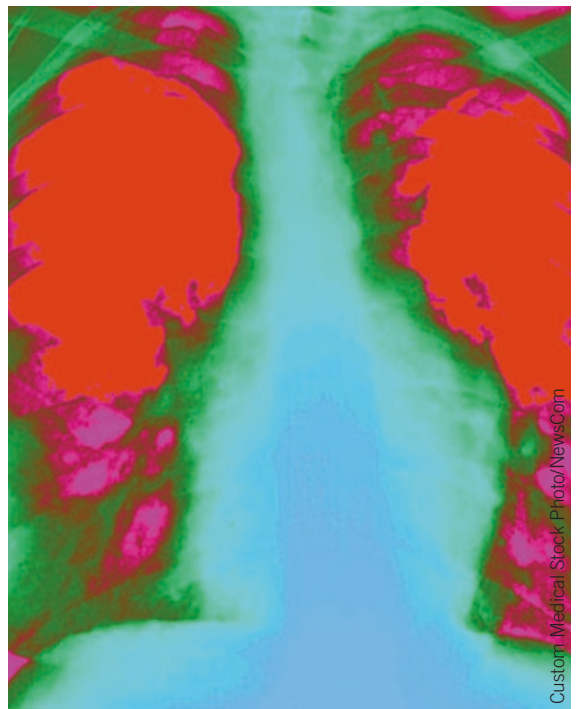

Niche indications such as pulmonary arterial hypertension (chest X-ray of diseased pulmonary arteries pictured here), have the potential to command good revenue streams.

Chow, a senior biotech analyst with Caris \& Company located in New York, would not consider biotechs to be trading inexpensively right now on the stock market, he thinks that the recent spate of acquisition activity bodes well for the future of biotech valuations. He cites the $\$ 1.1$ billion acquisition by Whitehouse Station, New Jersey-based Merck \& Co. of RNAi RNA interference technology company Sirna Therapeutics, a San Francisco, California-based firm, on October 30, 2006. This illustrates how early stage valuations of companies with a clear focus have come up in recent months. The deal was priced at a $100 \%$ premium to Sirna's closing price of $\$ 6.45$. That means that insiders at Merck thought the company was trading well below its proper valuation.

Although the Myogen-Gilead deal didn't fetch quite so significant a premium-only a $50 \%$ premium-it does say a lot about both Gilead's view of the future and their opinion of stock market pricing. With the bulk of their cash resources devoted to this one deal, it means insiders at Gilead, at least, are optimistic about the industry over the next 12 months and willing to back up their optimism with cash.

Of equal interest for the industry is the $\$ 2.5$ billion investment in cash that Gilead will make to purchase Myogen and how this investment dovetails with other biotech acquisition activity. "Earlier in the year, early-stage valuations were down because of the tight money policies that were followed by the Federal Reserve," says Chow. Because money was so much harder and more expensive to get then because of federal policy, companies were loath to part with any cash they had on the balance sheet. Now with companies increasingly willing to pay premium prices for acquisitions, it could mean that lower valuations are becoming history, at least for the time being.

Wall Street and industry insiders were expecting a more traditional suitor for Myogen: one that had an existing distribution network in respiratory indications that could be leveraged into cross-sales, for instance. However, some believe that Gilead can adjust to its new focus because of some existing strengths in niche sales. "Gilead's planned niche sales force should... be able to capitalize on the company's experience with similar developments in HIV," wrote Morningstar's Andersen in summarizing the benefits of the deal for Gilead in a note covering the acquisition.

Yet some analysts see the acquisition as more evolutionary than revolutionary for Gilead. They point to Corus Pharma of Seattle, another of Gilead's acquisitions, acquired August 11 2006 - a company which specializes in respiratory and infectious diseases-as a set up for the Myogen take-out. "Gilead has been definitely trying to grow the respiratory area," says Chow, pointing out that acquisition activity is typical for biotech companies later in the year.

Taken together, this type of acquisition activity could be a harbinger for continued high valuations for the biotech industry. One has to ask oneself: with industry insiders making premium purchases inside the industry with cash, which pricing view is right: Wall Street's market pricing or Biotech's deal pricing? While industry insiders are willing to pay large premium prices for acquisitions, Wall Street could eventually try to catch up with higher prices of their own on the stock markets. That's a combination for a classic bull market where biotech securities are on the rise.

John Ransom, Lone Tree, Colorado 